\title{
A Voice of Their Own?: The Role of Women in Contemporary Irish Poetry
}

\author{
Inés Praga Terente \\ Universidad de Valladolid
}

\begin{abstract}
This paper is an attempt to describe and evaluate the distinctively female voice in contemporary Irish poetry, concentrating on the works of Eiléan Ní Chuilleanáin, Eavan Boland, Medbh McGuckian and Nuala Ní Dhomhnaill. Both the private and the public dimension of their poetic output are analysed, with special reference to their attentiveness to ordinary life, their self-conscious femaleness, their concern for the past and their involvement in social and political affairs.
\end{abstract}

Any attempt to describe and evaluate the role of women in contemporary Irish poetry requires, first of all, the delimitation of the time and space under discussion. Some recent anthologies deal with this period but there are great differences in the authors and generations they cover. Some of them, for example, include poems written by Irish men and women, in English and in Irish, over the past thirty or forty years, mixing the younger generations with the leading figures of Kavanagh, Kinsella o MacNeice. The younger poets, for their part, have been the focus of several works that emphasize the distinctiveness of both their youth and the country they belong to. I should make it clear, first of all, that this paper will concentrate on the generation of poets born in the 1940s and early 1950 s who began to publish in the 1970 s, more or less, and established their reputation in that decade and throughout the 80s. The chronological limits having been stated, I should clarify the geographical boundaries of the present study by stating that every significant poet will be considered irrespective of whether she belongs to Northern Ireland or the Republic. In this way, I hope to avoid the well known controversy over competing claims between North and South for poetic leadership. It is generally recognized that the prominence achieved by the Ulster poets has obscured their Southern fellow writers, who put down the Northern poets' celebrity to their excellence but, at the same time, to the international echo of the Troubles and the support of Faber and Faber. At the same time, it has been repeated over and over again that poetry from the Irish 
Republic has been ignored by critics in England for many years and that there is no sense of Southern Ireland as a spawning ground for poetry.

None of these sectarian approaches will be adopted here. The only thing I would like to make clear is the richness and fertility of the poetry published in the island (both North and South), the best poetry written in the English speaking world in the last twenty years according to John Montague. He attributes the poetic fecundity to the pressures existing in both North and South, "two diseased bodies infecting each other with antiquated maladies, while the poets chant remedies. There is a sense in which Ireland has become a field of irreconcilable forces, from the craven refusal of the South to countenance abortion or divorce as necessary evils, to the religious racism of the North" (xvi).

As a matter of fact, the voices describing the landscape of contemporary Ireland are definitely pessimistic. Clifton depicts the Irish scene as "a generation of idle hands and empty hearts that have grown up cynically aware of state schemes to create illusory jobs, releasing its energies in crime and experimental theatre, electric music and emigration, groping blindly towards new religious forms, new matrices and relationship" (20). Sebastian Barry holds a similar viewpoint when he declares that "to be born in the fifties in the Republic of Ireland was to be born, with no great ceremony, nowhere. It was a country without definition, because it was a new place. But all the acceptance of foreign rule, the dominion of priests, the isolated desire for revolution - islands inside an island - had metamorphosed quaintly into dullness, dismay, and inaction" (18). What is clear is that most poets share nowadays what Garrat has defined as "the tradition of discontinuity," a deep sense of isolation and lack of identity. Poets can no longer celebrate the local and the familiar and there exists a great barrier between the poets and the community, most of them displaying a final inability to take root either at home or in the long list of places they visit. The central dilemma of their poetics is, undoubtedly, the fragmentation beween past and present and, between themselves and present-day Ireland, a conflict that seems to haunt them.

This account of Irish writing appears, formulated in different ways, in most of the prefaces to poetry anthologies and criticism. However, none of them had mentioned female poetry as a distinct and remarkable poetic group until the recent publication of The Penguin Book of Contemporary Irish Poetry, where a self-conscious women's poetry is presented as one of the main currents of present-day Irish poetry for the first time (xxi).

But to tell the truth, women's poetry has been underrated and neglected everywhere and not only in Ireland. The reasons, oversimplifying, are crystal clear: the publishing world was dominated by men and the word "poet" was definitely masculine. Only the muse seemed to be female. But while works by British or American women poets have been abundant, as well as criticism on them, Irish women poets have been virtually nonexistent until very recently. It is evident that Irish women present complexities which distinguish them from women working within other traditions. These complexities are clearly twofold, as they encompass both the female and national identity. Eavan Boland, one of the most authoritative voices in Irish poetry, describes them in terms of identification and does not hesitate to say that "womanhood and Irishness are metaphors for one another. There are resonances of humiliation, oppression and silence in both of them and I think you can understand one better by experiencing the other" (Wilson 84). 
In fact, the Irish literary tradition provides powerful, simplifying fusions of the feminine and the national, and Irish poets have coped with their sense of historical injury by writing of Ieland as an abandoned queen or an old mother. Women have become national icons in Irish literature and the abundant examples that could be mentioned make of Ireland, in literary terms, a silent woman, doubly silenced by her sex and her history. However, when we approach today any of the anthologies of women's poetry, it is amazing to discover the plurality of voices, the interplay between them, sometimes connecting, sometimes in counterpoint and contrast. It is amply proven that the silent woman has broken her age-old silence and achieved a voice of her own. But what I intend to examine throughout this essay is not only the existence of a female poetic voice but also, and above all, its particular features, if any, when compared to male voices. In other words, to find out whether or not this voice has shaped itself into a representative instrument speaking for women as an independent group or, on the contrary, is a voice expressing individual selfhood, wholeness, identity.

When Padraic Colum prefaced Eithne Strong's first volume, Songs of Living (1961), he underlined the character of the poems, which seemed to be uttered more by a priestess or a druidess than by a mortal woman:

I find it hard to describe the effect that these runes have on me. At its strongest the effect comes from a sense of solitariness: the voice has the tone of one who lives outside companies. The solitariness of voice as of one speaking from herself and for no other one, makes these poems remarkable.

Nevertheless, if we go on reading Strong's poetic output we will observe how much it evolves, and so the solitary voice of Songs of Living becomes the mouthpiece of domestic liberation in Sarah in Passing and the same voice assumes communal tones, similar to Patrick Kavanagh's, in Flesh, the Greatest Sin. That is to say, her voice becomes more and more collective.

Perhaps this development - from private to public experience or, in other words, from individual to collective identity and roles - should be viewed as essential and alternative positions of women writers in Ireland. Their search for identity, one of the recurrent themes of contemporary poets, takes place at the intersection of public and private life, causing inner conflicts and a serious dilemma in female poetry. The words of Ailbhe Smyth are crucial when she says that "women who write and who go on writing are by definition survivors. Women who refuse, in and through their writing, to accept the so called truths imposed upon them are by definition subversive" (14). But it is evident that survival and subversiveness are concepts that far from excluding each other, can co-exist or alternate throughout literary history. If we consider, though very superficially, the different positions and attitudes women had to adopt historically to become recognized writers, the difference would be inmense. A quick survey of their contribution should demonstrate that this has been as ancient as continous. Some of The Love Songs of Connaught were composed by women as well as a lot of popular ballads, using male pseudonyms, initials or pen names. This silence about their identity was to be maintained for centuries and if we turn to the seventeenth and eighteenth centuries we come across a 
lot of would-be writers making apologies to justify their literary activity, being reminded all the time of their prior duties as mothers, wives or simply daughters and sisters. Writing was definitely not a female task. The profile of the woman that gradually advances towards recognition as a writer is the following: well educated, socially influential and liberalminded. In the nineteenth century, women committed themselves to collective claims, playing an active and important role in the furthering of Irish nationalism. Very often their voices are highly sentimental and tearful, mixing national feeling and painful examples of domestic realism. And so the poems are full of orphans, dying mothers or dead heroes long mourned for. It was, in short, poetry based on sentiment - something, moreover, that has been considered a peculiarly suitable feminine field. These self-centered, self-pitying poems would present woman as a key element of the painful situations they depict. However, these poems by no means intrude on the privacy of womanhood.

It could be stated that this tearjerking voice is silenced at the turn of the century and between 1990-40 hardly any woman poet could be heard. The reasons are perhaps too complex to be dealt with in these boundaries but we cannot do without mentioning the sociological constrictions then existing. Families remained large and childbearing and rearing remained women's supreme function. Religious loyalties were also strong and as Terence Brown points out "Church teaching with its emphasis on the virtue of motherhood had been butressed by the constitutional affirmation of 1937 that 'by her life within the home woman gave to the state a support without which the common good cannot be achieved"' (304). In addition, the Censorship of Publications Acts affected woman in a very particular way and as far as legal and social discrimination go, a Commision on the Status of Women which reported in 1972 revealed how little Ireland had adapted its legal system to accommodate the rising expectations of women.

When we approach the generation of women poets born between 1940-50 we realize that they reached adulthood at the time of women's so called liberation. They belong, by age, to the period in which overt feminist poetry was published and read, the kind of poetry somewhat closer to claim than feeling. However, the poetry of Eiléan Ní Chuilleanáin, Eavan Boland, Medbh McGuckian and Nuala Ní Dhomhnaill, the four writers we are going to concentrate upon, doesn't show, taken as a whole, the radical or outspoken issues so prevalent in British or American women poets. As Boland declared recently "There is no doubt that most women poets now explore two strategies within poetry. There is a separatist strategy where women are trying to make the structures again and there is a subversive strategy. I am much nearer the second than the first. I want to subvert the old forms with tenderness and see what happens" (O'Siadhail 22). Boland's words could be applied, with very distinctive features in every case, to the average output of the women poets above mentioned. Their poetics cannot be considered apart from the general current we have described at the beginning of this paper. The sense of discontinuity and isolation we mentioned then can be traced in women's poetry with the same evidence. But we would dare say women explore this discontinuity on the private level rather than on the public one. Thus, they are particularly concerned with selfhood and identity and their domestic realms whereas scarce attention is devoted to politics or public affairs. None of them admits being a feminist in the sense of belonging to a concrete 
movement or party but they all express deep concern about women, the women's world and female experience.

A well known poem by Eavan Boland, "It's a woman's world," provides us with the two contexts women's poetry mainly explores: hearth and history:

\author{
When the King's head \\ gored its basket \\ grim harvest \\ we were gristing bread \\ or getting the recipe \\ for a good soup \\ It's still the same \\ our windows \\ moth our children \\ to the flame \\ of hearth not history \\ And still no page \\ scores the low music \\ of our outrage. (Selected Poems 51-52)
}

Hearth and history, or in other words, the domestic and the cultural, seem to be opposed elements not only in Boland's poetry but in the rest on the women poets we are refering to. Opposed elements, we have just said, but not necessarily excluding each other because, as we shall see, some of these writers show a considerable balance between the two. If we were to highlight a feature all of them share that would be their delicate attentiveness to ordinary life, both to its settings and its activity. They all display a remarkable sensitiveness to catch the meaning and value of apparently insignificant objects revising carefully not only the object itself but the personal story the object belongs to. However, the domestic settings range widely in every poet. Boland, for example, pays extraordinary attention to "the lesser lives women lead in suburban houses," houses full of children, dishes, clothing and electric appliances. She epitomizes perfectly the average urban Irish woman and the dullness that presides her daily life, as we can see in "Woman in Kitchen":

Breakfast over, islanded by noise,

She watches the machines go and fast

She stands among them as they shake the house.

They move. Their destination is specific.

She has nowhere definite to go.

She might be a pedestrian in traffic.

The wash done, the kettle boiled, the sheets

Spun and clean, the dryer stops dead.

The silence is a death. It starts to bury

The room in white spaces. She truns to spread 
A cloth on the board and irons sheets

In a room white and quiet as a mortuary.

(Selected Poems 43)

The house and its objects play an important role as well in Ní Chuilleanáin's poetry, objects which take on a life of their own, especially in her latest book The Magdalene Sermon full of domestic tenderness. "MacMoransbridge" is a good example of a life recorded in a man's belongings:

Although the whole house creaks from their footsteps

The sisters, when he died,

Never hung up his dropped dressing gown

Took the ash from the grate, or opened his desk. His will,

Clearly marked, and left in the top drawer

Is a litany ob objects lost like itself ...

The tarnished silverpot, to be sold

And the money given to a niece for her music lesson

Is polished and used on Sundays. The rings and pendants

Devised by name to each dear sister are still

Tucked between silk scarves in his wardrobe, where he found

And hid them again, the day they buried their grandmother. (19)

And the domestic is undoubtlessly the main feature of MacGuckian's poetry, though her settings are hardly identifiable. The house, a symbol so frequent in her poetry, stands for the self, the identity, and so her poems are full of instinctive relations to domestic places or cosmic forces. For McGuckian, house and woman are equivalent terms in her continuous exploration of the inner conflicts of womanhood. Woman is a house, or seeks refuge in a house, but in both cases is a house full of tensions, above all tensions between male and female that are, in her own words, "absolutely opposite tensions...two different kinds of creativity pulling against each other" (Wilson 5). "Gateposts," one of her best known poems, shows that clearly:

Under the hip-roofed thatch, The bed-wing is warmed by the chimney breast;

On either side the keeping-holes

For his belongings, hers.

He says it is unlucky to widen the house

And leaves the gateposts holding up the fairies

He lays his lazy-beds and burns the river,

He builds turf-castles

And springs the corn with apple-mint.

She spreads heather on the floor

And sifts the oatmeal ark for thin-bread farls:

All through the blue month 
She tosses stones in basins to the sun,

And watches for the trout in the holy well.

As a whole we could say that her poems are so self-referential and the tone of her voice so confessional that her focus and boundaries are really different from those of the other women poets. Both the psychological intensity and the lyrical descriptions impinge on her poetry, producing some of the best poems about Nature. Flowers, plants, gardens, rivers, stars, are the ordinary contexts for the "woman as goddess" she creates in books like Venus and the Rain or The Flower Master. Her poetry is obscure, disjointed, highly individual and in Colum's words we could say that "she speaks out of companies."

The degree of privacy and intimate experience each of these poets shows is also very different. They all deal with love as a recurrent theme, Nuala Ní Dhomhnaill standing out for her sensuousness in poems such as "Island," "Without your clothes," "I Cannot Lie Here," or "Aubade" and Eavan Boland being perhaps less concerned about this topic than the rest. However, Both Boland and Ní Dhomnaill celebrate motherhood in several poems, such as Boland's "The Gorgon Head" or "The Oral Tradition," though perhaps it is Ní Dhomhnaill who has described the physical dimension of pregnancy, childbirth and childbearing with more intensity. She mixes the exalted maternal tones of "Poem for Melissa":

Oh white daughter here is your mother's word:

I will put in your hand the sun and the moon

I will stand my body between the millstones

In God's mills so you are not totally ground

with more delicate subjects like, for example, abortion in "Miscarriage in London."

However as far as taboo subjects go, it could be stated that they are not frequent in women poets' output. Contraception, sex, abortion and topics of this kind are too controversial to be dealt with in a country like Ireland but even so, women poets dare now to write about their bodies. In this sense, we should stress the value of Eavan Boland's book In her Own Image, in which she approaches very delicate matters such as menstruation ("Menses"), mastectomy, anorexia or masturbation, ("Solitary"), with as much tactfulness as directness:

Flames

Single

To my fingers

Expert

To pick out

Their heart,

The secret heat

None may violate. 
I know

Only I know

These incendiary

And frenzied ways:

I am alone. (Selected Poems 38)

Such poems, however, were misunderstood and as Boland herself puts it "Only in Ireland would it have been taken to be some kind of free-fall through feminist ideology. The book is an examination of the responsibilities of the poet to the silences which surround human experience" (Wilson 82-3). Domestic life, home, love, motherhood are, as we have said, essential elements for women poets but by no means the most important ones. The four writers show deep concern for the links between past and present though, as above, their different approach should be discussed. Boland and Ní Dhomhnaill stand out for their interest in ancient Ireland. The former has made clear her identification with past lives rather than past heroic events : "I would always choose a past that was real and actual and was composed of private, enduring human dignities. I do not want songs to be sung at midnight but lives that were lived and lost and lived again" (Wilson 84). Her poem "The Famine Road" illustrates that point perfectly:

Sick, directionless they worked; fork, stick were iron years away; after all could they not blood their knuckles on rock, suck April hailstones for water and for food? (Selected Poems 19)

Nonetheless, Boland is aware of the myths which have traditionally sustained males and she would like equivalent myths for females but her sense of utter loss is realistic: modern day Dubliners have been cut off from the power of myth and history and their lives, therefore, are completely alienated and empty. For Boland, as we have seen before "Hearth and History" do not go together.

The case of Nuala Ní Dhomhnaill remains somewhat apart since she writes in Irish and we must read her in the translations - which are, incidentally, excellent - of M. Hartnett or M. Longley. For her, the fact of having adopted Irish as her poetic language has a great value: that of prolonging tradition: “The Irish language wasn't industrialized or patriarchalized, Irish is the language of the Mothers, because everything that has been done to women has been done to Irish" (Wilson 154). The past is a key element in Ní Dhomhnaill's poetry, a poetry that tries to tell the "long history suffering women have." In this sense, her poetry is closer to the past than any other, not only because of her solidarity with women's history, but because of her interest in mythology and folklore, both elements being essential to suppy her poetry with the magical atmosphere it frequently creates. For her, being a poet means "that you are mediating between the other world, the lios, and this world" (Wilson 153), a fact that is evident in poems like "The Bond" or "The Race."

But the poetic features we have just mentioned, the deep concern for a past of strife and deprivation and the magical and surrealistic dimension, lead us directly to Eiléan Ní 
Chuilleanáin's poetry. Having been frequently labelled as an "obscure poet" by critics, Ní Chuilleanáin posseses an amazing handling of classical themes like, for example in "Odysseus Meets the Ghosts of the Women":

He saw the daughters, wives

Mothers of heroes or upstanding kings

The longhaired goldbound women who had died

Of pestilence, famine, in slavery

And still queens but they did not know

His face, even Anticleia

His own mother. He asked her how she died

But she passes by his elbows, her eyes sleep.

Her poetry, sometimes too personal to be shared, holds a startling viewpoint, a unique perspective that endows her poems with a touch of unreality like, for example, "The Informant" or "The Voice." Therefore, when compared to the other women poets, Medbh McGuckian shows an utter lack of roots in Irish mythology and folklore. "I think my temperament is coloured by living on this island, my identity, my home, is very much fixed to the North ... In a way I am an English poet trying to reverse into an Irishness that is an impossible dream ... We are all just adopted. Ireland doesn't care about us, nor England. We feel we don't have any roots" (Wilson 5). Just a very few of her poems deal specifically with the Irish dimension so clear, in one way or another, in the rest of the women poets. We could suppose, then, that her poetry is focused on present day problems, unhappily so frequent in Belfast where she lives. However, McGuckian's poetry doesn't reflect at all the violent atmosphere sourrounding her. She refers to violence and death as prior facts for her life and personality but "What I tend to do is gloss over them, or use poetry to control horror and evil, to make them not less important but to put them into their overall context. It is a game of not facing reality but if I didn't have it I would be insane" (Wilson 2).

Considered as a whole. McGuckian's poetry lacks the direct and accusatory tones of other Northern poets, such as Paulin or Carson, just to mention two of them. And we would state that this absence of what we would call "public dimension" is common to the four women poets we are dealing with. Their poetic voice is definitely self-centered and self-referential and in some way "out of company," to repeat Colum's words. Generally speaking, all of them avoid politics and nationalistic or religious issues although a gradual advance from privacy to public affairs is taking place in female poetry. The voice of Eavan Boland is undoubtlessly the mouthpiece of women's present reality. She seems free to apply her femaleness to any kind of experience without feminizing or distorting it. Simply, she focuses reality as a woman.

However, we have been discussing the contribution of women to the Irish poetic scene, women being considered as subjects of poetry and, but for limitations of space, we would like to pay some attention to the role of women as objects of contemporary poetry. It seems impossible to compare the female image women reflect in their own poems and the same image explored throughout poetry by male writers. Paul Durcan, to give just one 
example, devotes extraordinary attention to women in all his books and has shown a powerful insight into the subservient role of women in Irish society. Going Home to Russia, for example, can be considered a book about women and in Daddy, Daddy poems like "Phyllis Goldberg" or "Felicity in Turin" illustrate his knowledge and familiarity with the women's world. His latest book, Crazy About Women, written to celebrate the Painting Exhibition of the National Gallery of Ireland, displays his exquisite and deep concern for female issues. However, if we had to point out the main difference between Paul Durcan's approach to the female world and that of women themselves, it would be the relaxed and humorous viewpoint so common in Durcan and completely absent from women poets' work. Women seem to find it more difficult to pull down the barriers of their privacy and make it into a topic to be discussed, contrasted and why not? parodied. But when we talk about the still shy tone of women's voice, we should take into account that the younger generations are enlarging the scope of female poetry by adding new tones of voice and, above all, less inhibited attitudes. We should mention, for example, the comic teasing of Julie O'Callagham in poems like "A Tourist Comments on the Land of his Forefathers" or the down to earthness of Rita Ann Higgings, just to mention two of them.

But soft as they may be, perhaps too soft, the fact is that female voices make up an essential choir in Irish contemporary poetry. Just four authors have been discussed here but it would be interesting to examine the importance of women in the world of poetry not only as writers but as poetry workshop organizers, like Eavan Boland or popular poetry readers, like Nuala.

Ireland is no longer a silent and submitted woman, the image both legend and literature had formed throughout the centuries. Ireland is now the frame of numerous women in search of an identity and a voice of her own. A voice that covers a profusion of themes and perspectives, images and strategies, disagreements and affinities. And the search for a language, a voice of their own, may be one of the reasons why Irish women are so strongly drawn towards poetry because as McGuckian has said "poetry is what we are not allowed to talk about." A voice, in other words, to tell the unspoken and unwritten history of women, because as Ní Chuilleanáin says

Our history is a mountain of salt

A leaking stain under the evening cliff

It will be gone in time

Grass will grow there

Not in our time. (The Magdalene Sermon 11)

\section{Works Cited}

Adlock, Fleur. The Faber Book of Women's Twentieth Century Poetry. London: Faber and Faber, 1987.

Barry, Sebastian, ed. The Inherited Boundaries: Younger Poets of the Republic of Ireland. Dublin:

The Dolmen Press, 1987. 
Boland, Eavan. In her Own Image. Dublin: Arlen House Press, 1980.

The Journey. Manchester: Carcanet Press, 1987.

- Night Feed. Dublin: Arlen House Press, 1982.

- Selected Poems. Manchester: Carcanet Press, 1989.

- The War Horse. Dublin: Arlen House Press, 1975.

Brown, Terence. Ireland: A Social and Cultural History. 1922-1985. 4th edition. London: Fontana

Press, 1987.

ed. Tradition and Influence in Anglo Irish Poetry. London: McMillan, 1989.

Clifton, Harry." Available Air: Irish Contemporary Poetry, 1975-1985." Krino, no. 7 (1989): 20-30.

Ní Chuilleanáin, EiléanActs and Monuments. Dublin: Gallery Books, 1972. ed. Irishwomen: Image and Achievement. Dublin: Arlen House Press, 1985. . The Magdalene Sermon. Dublin: Gallery Books, 1989.

Dawe, Gerald, ed. The New Younger Irish Poets. Belfast: The Blackstaff Press, 1991.

Dhomhnaill, Nuala. Selected Poems. Dublin: Raven Arts Press, 1986.

Dunne, Sean, ed. Poets of Munster. London: Anvil Press Poetry, 1985.

Durcan, Paul Daddy, Daddy. Belfast: The Blackstaff Press, 1990. . Going Home to Russia. Belfast: The Blackstaff Press, 1987.

. Crazy About Women. Dublin: The National Gallery of Ireland, 1991.

Fallon, Peter, ed. The Penguin Book of Contemporary Irish Poetry. Hardmonsworth: Penguin Books, 1990.

Gallaher, S. F., ed. Woman in Irish Legend, Life and Literature. Gerards Cross: Colin Smythe, 1983.

Garrat, Robert F. Modern Irish Poetry. Berkeley: University of California Press, 1989.

Kelly, A. A., ed. Pillars of the House: An Anthology of Verse by Irish Women from 1690 to the Present. Dublin: Wolfhound Press, 1987.

McGuiness, Arthur E. "Hearth and History: Poetry by Contemporary Irish Women" Cultural Contexts and Literary Idioms in Contemporary Irish Literature.Ed. Michael Kenneally. Gerrads Cross: Colin Smythe, 1988.

McGuckian, Medbh. The Flower Master. Oxford: Oxford U. P, 1982. . On Ballycastle Beach. Oxford: Oxford U. P., 1988.

Venus and the Rain. Oxford: Oxford U. P., 1984.

Montague, John, ed. Bitter Harvest. An Anthology of Contemporary Irish Verse. New York: Scribner's Sons, 1989.

Muldoon, Paul, ed. The Faber Book of Contemporary Irish Poetry. London: Faber and Faber, 1986.

O’Siadhail, Micheal. “An Interview with Eavan Boland." Poetry Ireland 27 (1989): 20-24.

Strong, Eithne. Flesh... The Greatest Sin. Dublin: Runa Press, 1980. . Sarah, in Passing. Dublin: The Dolmen Press, 1974. . Songs of Living. Dublin: Runa Press, 1961.

Smyth, Ailbhe, ed. Wildish Things. An Anthology of New Irish Women's Writing. Dublin: Attic Press, 1989.

Wilson, Rebecca E. Sleeping with Monsters: Conversations with Scottish and Irish Women Poets. Dublin: Wolfhound Press, 1990. 